NEWS

\title{
Professional Educational Opportunities
}

\author{
Sigmund Hough ${ }^{1}$
}

(c) Springer Science+Business Media, LLC, part of Springer Nature 2020

\section{Academy of Spinal Cord Injury Professionals}

- Annual ASCIP Educational Conference \& Expo, September 5-8, 2021. San Diego, CA.

\section{American Academy of Physical Medicine and Rehabilitation}

- Annual Assembly, November 12-15, 2020. San Diego, CA.

\section{American Association of Sexuality Educators, Counselors and Therapists}

- Annual AASECT Conference, June 10-13, 2021. Tampa. FL.

\section{American Association on Intellectual and Developmental Disabilities}

- AAIDD Annual Meeting, June 21-24. 2021. Jacksonville, FL.

\section{American Congress of Rehabilitation Medicine}

- Annual ACRM Conference, September 26-20, 2021. Dallas, TX.

Note: Please go to the organization's main website for the latest information regarding status and possible cancellation related to the impact of COVID-19.

Sigmund Hough

Sigmund_Hough@hms.harvard.edu

1 Beverly, USA 


\section{American Psychiatric Association}

- Annual Meeting, May 1-5, 2021. Los Angeles, CA.

\section{American Psychological Association}

- Annual Conference, August 12-15, 2021. San Diego, CA.

- Annual Conference, August 4-7, 2022. Minneapolis, MN.

\section{American Spinal Injury Association}

- Annual ASIA Scientific Meeting, July 8-10, 2021. St. Louis, MO.

\section{American Urological Association}

- Annual Meeting, September 10-13, 2021. Las Vegas, NV.

\section{Association for Behavioral and Cognitive Therapies}

- Annual Conference, November 19-22, 2020. Philadelphia, PA.

\section{Association for Persons with Developmental Disabilities and Mental Needs}

- NADD Conference and Exhibit Show, November 4-6, 2020. Cambridge, MA.

\section{Association for Psychological Science}

- Annual Convention, May 27-30, 2021. Washington, DC.

\section{Congress of the European Society for Sexual Medicine}

- Annual Congress Meeting, February 18-20, 2021. Rotterdam, The Netherlands. 


\section{International Society for Sexual Medicine}

- Annual Meeting, November 15-17, 2021. Yokohama, Japan.

\section{International Society for the Study of Women's Sexual Health}

- Annual Meeting, March 4-7, 2021. Dallas, TX.

\section{Learning Disabilities Association of America}

- Annual International Conference, February 18-21, 2021. New Orleans, LA.

\section{Paralyzed Veterans of America}

- Annual PVA Healthcare Summit, August 30 - September 1, 2021. Dallas, TX.

\section{Sexual Medicine Society of North America}

- SMSNA Annual Fall Scientific Meeting, October 21-24, 2021. Scottsdale, AZ.

\section{Society for Social Work and Research}

- Annual Conference, January 20-24, 2021. San Francisco, CA.

\section{The Society for Sex Therapy and Research}

- Annual Meeting (Virtual Conference), April 24, 2021.

\section{The Society for the Scientific Study of Sexuality}

- Annual Meeting, November 19-22, 2020. New Orleans, LA. 


\section{University of Guelph}

- Annual Sexuality Conference, June 18-19, 2020. University of Guelph, Ontario, Canada.

\section{YAI/NIPD Network's International Conference and Trainings}

- See website for training information, www.yai.org. YAI Central Office, New York, NY.

Publisher's Note Springer Nature remains neutral with regard to jurisdictional claims in published maps and institutional affiliations. 